\title{
Article \\ Effects of Rice Husk Biochar Coated Urea and Anaerobically Digested Rice Straw Compost on the Soil Fertility, and Cyclic Effect of Phosphorus
}

\author{
Ashoka Gamage ${ }^{1, *}$, Ben Basnayake ${ }^{2}$, Janendra De Costa ${ }^{3}$ and Othmane Merah ${ }^{4,5, *(D)}$ \\ 1 Department of Chemical and Process Engineering, Faculty of Engineering, University of Peradeniya, \\ Peradeniya 20400, Sri Lanka \\ 2 Department of Agricultural Engineering, Faculty of Agriculture, University of Peradeniya, \\ Peradeniya 20400, Sri Lanka; nri.srilanka@gmail.com \\ 3 Department of Crop Science, Faculty of Agriculture, University of Peradeniya, Peradeniya 20400, Sri Lanka; \\ janedrad@gmail.com \\ 4 Laboratoire de Chimie Agro-Industrielle (LCA), Université de Toulouse, INRA, 31030 Toulouse, France \\ 5 Département Génie Biologique, Université Paul Sabatier, IUTA, 32000 Auch, France \\ * Correspondence: ashogamage@gmail.com (A.G.); othmane.merah@ensiacet.fr (O.M.); \\ Tel.: +94-714-430-7141 (A.G.); +33-(0)5-34-32-35-23 (O.M.)
}

Citation: Gamage, A.; Basnayake, B.; De Costa, J.; Merah, O. Effects of Rice Husk Biochar Coated Urea and Anaerobically Digested Rice Straw Compost on the Soil Fertility, and Cyclic Effect of Phosphorus. Plants 2022, 11, 75. https://doi.org/ 10.3390/plants 11010075

Academic Editor: Jim Moir

Received: 22 November 2021

Accepted: 20 December 2021

Published: 27 December 2021

Publisher's Note: MDPI stays neutral with regard to jurisdictional claims in published maps and institutional affiliations.

Copyright: (c) 2021 by the authors Licensee MDPI, Basel, Switzerland. This article is an open access article distributed under the terms and conditions of the Creative Commons Attribution (CC BY) license (https:// creativecommons.org/licenses/by/ $4.0 /)$.

\begin{abstract}
Fertilizer application in rice farming is an essential requirement. Most of the high-yielding varieties which are extensively grown throughout the country require recommended levels of fertilizers to obtain their potential yields. However, effective, and efficient ways of fertilizer application are of utmost importance. Coated fertilizers are used to reduce leaching nutrients and improve the efficiency of fertilizer. However, conventional coated fertilizers such as Sulphur coated urea and urea super granules are not popular among rice farmers in Sri Lanka owing to the high cost. Mixing urea-coated rice husk biochar causes a slow release of nitrogen fertilizer. This coated fertilizer and rice straw compost reduction the cost of importations of nitrogen-based fertilizers per unit area of cultivation. The study aimed to evaluate the effects of rice husk biochar coated urea and anaerobically digested rice straw compost on the soil fertility, and the cyclic effect of phosphorus. Concerning the pot experiment, rice grain yield was significantly higher in Rice husk biochar coated urea, triple super phosphate (TSP), and muriate of potash (MOP) with anaerobically digested rice straw compost. The lowest yield was observed in the control. The release of phosphate shows a cycle effect which is an important finding. Rice husk biochar coated urea can potentially be used as a slow-releasing nitrogen fertilizer. In addition, the urea coated with biochar is less costly and contributes to mitigating pollution of water bodies by inorganic fertilizers (NPK).
\end{abstract}

Keywords: anaerobically digested compost; cyclic effect; leaching; rice husk biochar; slowreleasing fertilizer

\section{Introduction}

Agriculture plays an important and strategic role in the performance of the Sri Lankan national economy contributing nearly $8.4 \%$ of the gross domestic product (GDP) [1] Presently, Sri Lanka produces 2.3 million metric tons (MMT) of rough rice (paddy) with a national average yield of 4.3 MT/ha in the 2017/2018 Maha seasons [1].

With the introduction of High Yielding Varieties (HYV), the provision of incentives to apply more chemical fertilizers. This was initiated in Sri Lanka in the year 1962. The HYVs are highly responsive to chemical fertilizers and hence it was essential to apply fertilizers to achieve expected yields. The increased pressure to maintain a high level of rice output for consumption has resulted in the increased use of inorganic fertilizer in rice fields in Sri Lanka [2]. The subsidy was limited to the main nitrogen fertilizer urea during 1997-2004. In 
the year 2005, the subsidy has again been expanded. Since 2005-2015, the subsidy provided for all three main fertilizers (N, P, and $\mathrm{K})$ at a fixed price.

At present, urea is the foremost nitrogen fertilizer $(60-70 \%)$ used in Sri Lanka. Urea is the major source of supply of nitrogen fertilizer to crop production. Urea was imported to Sri Lanka during 2015-2017 has been for agricultural use. Urea has a nitrogen content of $46 \%$ is used in rice cultivation. The recovery of applied nitrogen to wetland rice is around $20-40 \%$ [3-6]. However, $\mathrm{N}$ application rates on agricultural fields often exceed the actual crop use and the unused $\mathrm{N}$ in the soil profile is either removed through leaching, denitrification, or volatilization. The nitrate ion is negatively charged and is not retained by the soils; thus, the dominant form of nitrate is leached from the soil [7,8]. Nitrate leaching which causes contamination of groundwater has become a major concern worldwide, mainly because of the intensification of agricultural productivity [9]. Rising nitrate concentration in groundwater has been detected in developing countries such as India and Sri Lanka where agricultural production has been intensified through the application of urea above the recommended levels [10]. Studies conducted on groundwater within intensively cultivated areas typically had nitrate-nitrogen concentrations in the range of 10-15 mg N/L compared to $0.2 \mathrm{mg} \mathrm{N} / \mathrm{L}$ in non-cultivated lands. There is a correlation between groundwater quality and land use [11]. WHO standard in the year 2011 for nitrates concentrations in drinking water is $10 \mathrm{mg} \mathrm{N} / \mathrm{L}$.

Many phosphorus $(\mathrm{P})$ sources contaminate surface waters. These sources are agriculture, municipal sewage treatment plants, individual septic treatment systems, decaying plant material, runoff from urban areas and construction sites, stream bank erosion, and wildlife. The addition of phosphorus to surface water accelerates the eutrophication process, in which the water becomes overly enriched with nutrients [6]. Clune [12] indicated that total P should not exceed ranged from 0.010 to $0.053 \mathrm{mg} / \mathrm{L}$ in a stream and revers.

Biochar is a charcoal carbon product derived from biomass that enhances soils, sequesters or store carbon, and provides useable energy. Biochar is produced by thermal decomposition of organic material under an anaerobic condition (or limited supply of oxygen) and at relatively low temperatures $\left(<700^{\circ} \mathrm{C}\right)[13]$.

Biochar is a porous substance containing high levels of carbon and various functional groups. The addition of biochar to agricultural soil enhances soil physicochemical properties [14], enzymes activity, microbial activity, and microbial diversity [15]. However, the interactions between biochar and microbial activities in soil are not fully understood [15]. The application of biochar to soil could increase soil nutrient levels and crop productivity by reducing leaching losses and even supplying nutrients to the crops.

Mixing both urea and biochar in soils creates a slow release of nitrogen fertilizer and increases nitrogen retention [16], thus increasing the efficiency and reducing the cost of nitrogen-based fertilizers. Biochar has been found to adsorb a variety of heavy metals, including lead (Pb), arsenic (As), and cadmium (Cd) [17]. Biochar also slowed the downward movement of pesticides, thus potentially reducing the risk of groundwater contamination [18]. There are only a few methods available for rice husk and rice straw reuse in Sri Lanka. A significant amount of rice husk and straw remains unused and burned in open fields, causing serious environmental and health problems. The concept of producing biochar using rice husk and producing rice straw compost is practicable in Sri Lanka because about 1.8 million farm families are engaged in rice cultivation island wide. It is of utmost importance to manage the agricultural wastes while providing a value-added useful product for increasing agricultural productivity and protecting the environment. Therefore, this study aimed to evaluate the effects of rice husk biochar coated urea and anaerobically digested rice straw compost on soil fertility, and the cyclic effect of phosphorus. Furthermore, determine the behavior of rice husk biochar coated urea and evaluate the leaching losses of nutrients. 


\section{Results}

\subsection{Proximate Analysis of Soil}

The results indicated that the physicochemical properties of soil had much more influence on the morphological characters of the growth of rice plants (Table 1). Soil electrical conductivity indicates soluble nutrients, and it is useful in monitoring the mineralization of organic matter in -rich soil. The soil $\mathrm{pH}$ regulated the enzyme activity of soil and helped the solubility of the nutrients. Bulk density is an indicator of soil compaction, increases with time as particles settle after puddling is halted. Bulk density is inversely related to many important soil properties. These are water-holding capacity, soil particle size, total porosity, infiltration capacity, hydraulic conductivity, gas exchange, and nutrient mobility.

Table 1. Physicochemical proprieties of the soil.

\begin{tabular}{cc}
\hline Properties & Soil \\
\hline Moisture content $\%$ & $2.94 \pm 0.120$ (air dried) \\
Bulk density $\left(\mathrm{g} / \mathrm{cm}^{3}\right)$ & $1.3 \pm 0.040$ \\
$\mathrm{pH}$ & $5.2 \pm 0.028$ \\
Carbon content $\%$ & $0.6 \pm 0.006$ \\
Total Nitrogen $(\mathrm{mg} / \mathrm{kg})$ & $300 \pm 8.16$ \\
Phosphorus $(\mathrm{mg} / \mathrm{kg}$ & $7 \pm 0.0 .12$ \\
Potassium $(\mathrm{mg} / \mathrm{kg})$ & $500 \pm 10.8$ \\
Electrical conductivity $(\mu \mathrm{s} / \mathrm{cm})$ & $89.1 \pm 0.817$ \\
Salinity $\%$ & $\mathrm{NA}$ \\
Texture & Sandy loam
\end{tabular}

NA-not available. Each value represents the mean of three samples.

\subsection{Pot Experiment}

Rice Plant Vegetative Growth

The significantly highest $(p<0.05)$ plant height can be observed in the inorganic fertilizer followed by anaerobically digested rice straw compost treatment (treatment 3) while the control had the lowest. However, plant height was faster in the treatment using inorganic fertilizer (treatment 1) than in the biochar coated urea treatment (treatment 2) from 12 to 71 days after transplanting. After 71 days, plant heights were similar in all treatments (Figure 1). The number of tillers was highest in treatments 1, followed by 3 and 4 compared to the other treatments (Table 2). All fertilizer treatments, irrespective of the use of urea coated biochar or compost showed a significantly $(p<0.05)$ higher number of panicles per hole than the unfertilized control (Table 2). However, there were no significant differences in tiller number between different fertilizer combinations. Rice grain yield was significantly greater in treatments 4 and there was no significant difference in treatment, 2, 3 , and 1 (Table 2). The lowest yield was observed in treatment 5 which is control and no addition of inorganic fertilizers.

There was a significant increase in biomass (dry matter) of the rice plant with the application of amendments as compared to the control (Table 2). The mean total dry biomass for treatment 4 was significantly higher than the means for all other treatments. The mean total dry biomass for treatments 1 and 3 was significantly higher than the means for treatments 2 and 5. The mean total dry biomass for treatment 2 (biochar coated urea) was significantly higher than that of treatment 5 . 


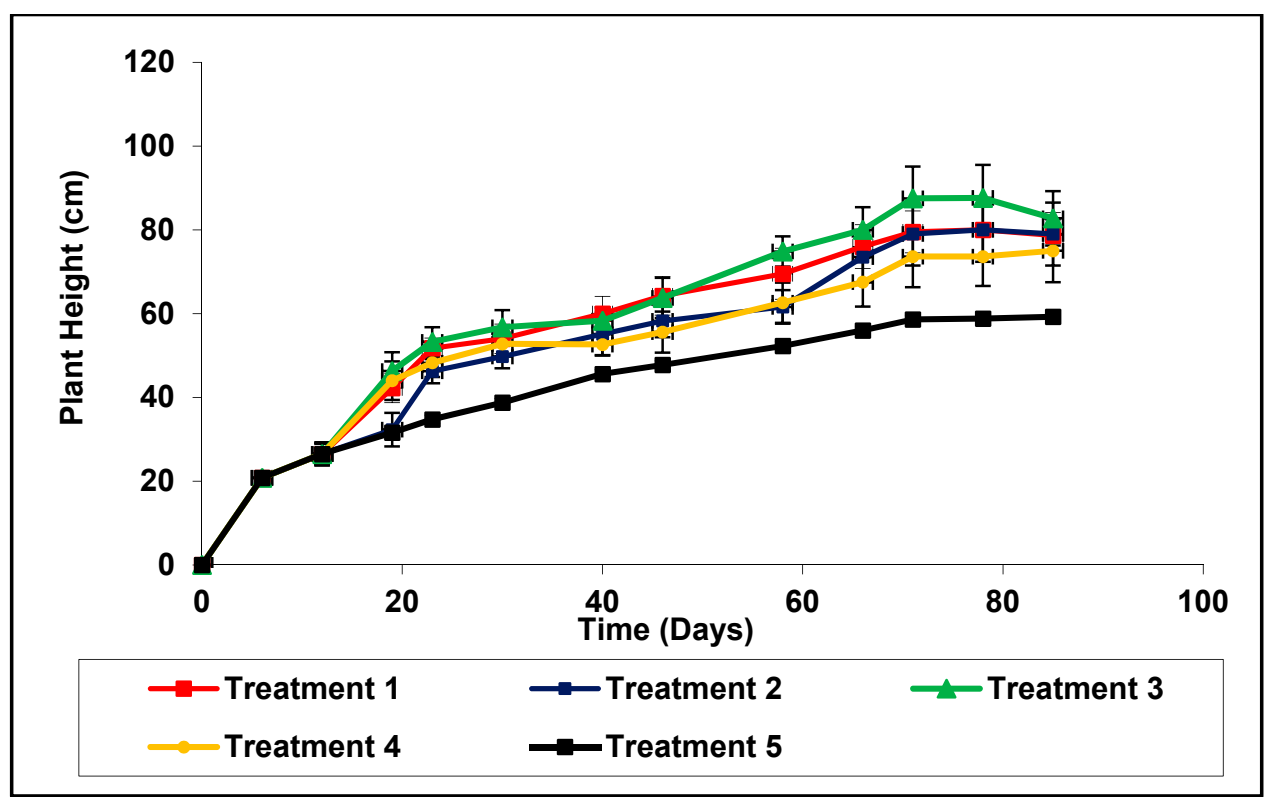

Figure 1. Variation of plant height with time in the pot experiment. Each data point is a mean of four replicates. Treatment 1 - inorganic fertilizer only (Urea, TSP and MOP), Treatment 2 - rice husk biochar coated Urea, TSP and MOP, Treatment 3- inorganic fertilizer (Urea, TSP and MOP) with anaerobically digested rice straw compost only, Treatment 4 - rice husk biochar Urea, TSP and MOP with anaerobically digested rice straw compost and Treatment $5-$ no fertilizer as control.

Table 2. Effect of different treatments on the growth and yield parameters of rice cultivated in pots.

\begin{tabular}{ccccc}
\hline Treatment & Dry Matter (g) & Number of Tillers per Pot & Number of Panicles per Pot & Yield (kg/ha) \\
\hline 1 & $63.02^{\mathrm{b}} \pm(0.93)$ & $12.25^{\mathrm{a}} \pm(2.50)$ & $8.0^{\mathrm{a}} \pm(0.50)$ & $4359.18^{\mathrm{b}} \pm(948.00)$ \\
2 & $50.83^{\mathrm{c}} \pm(0.86)$ & $9.75^{\mathrm{a}} \pm(2.06)$ & $7.66^{\mathrm{a}} \pm(0.90)$ & $3763.26^{\mathrm{b}} \pm(771.00)$ \\
3 & $61.01^{\mathrm{b}} \pm(0.70)$ & $11.25^{\mathrm{a}} \pm(0.50)$ & $8.33^{\mathrm{a}} \pm(0.66)$ & $4648.97^{\mathrm{b}} \pm(191.00)$ \\
4 & $65.03^{\mathrm{a}} \pm(1.25)$ & $11.25^{\mathrm{a}} \pm(2.50)$ & $8.10^{\mathrm{a}} \pm(0.52)$ & $5081.63^{\mathrm{a}} \pm(115.10)$ \\
5 & $27.82^{\mathrm{d}} \pm(2.26)$ & $7.25^{\mathrm{b}} \pm(0.95)$ & $5.00^{\mathrm{b}} \pm(0.77)$ & $891.83^{\mathrm{c}} \pm(163.36)$ \\
\hline
\end{tabular}

Mean followed by the same letter at each column are not significantly different $(p<0.05)$, each value represents the mean of four replicates. SD is given in parenthesis. Treatment 1 - inorganic fertilizer only (Urea, TSP, and MOP); Treatment 2 - rice husk biochar coated urea TSP and MOP; Treatment 3 - inorganic fertilizer (Urea, TSP, and MOP) with anaerobically digested rice straw compost only; Treatment 4- rice husk biochar urea, TSP and MOP with anaerobically digested rice straw compost and Treatment $5-$ no fertilizer as the control.

Total $\mathrm{N}$ (organic and inorganic $\mathrm{N}$ ) of the soil of treatment 1 increased during the first 12 days and then gradually decreased until 19 days and subsequently increased (Figure 2a). Total $\mathrm{N}$ in the soil of treatment 2 was maintained almost the same throughout the period. Total $\mathrm{N}$ in the soil of treatment 3 increased during the first 12 days and later on decreased gradually until days after planting and again increased. Soil nitrate-nitrogen of treatment 1 increased during the first 12 days and then gradually decreased until 19 days and subsequently increased (Figure 2b). Nitrate in the soil of treatment 2 was maintained almost the same throughout the period. 

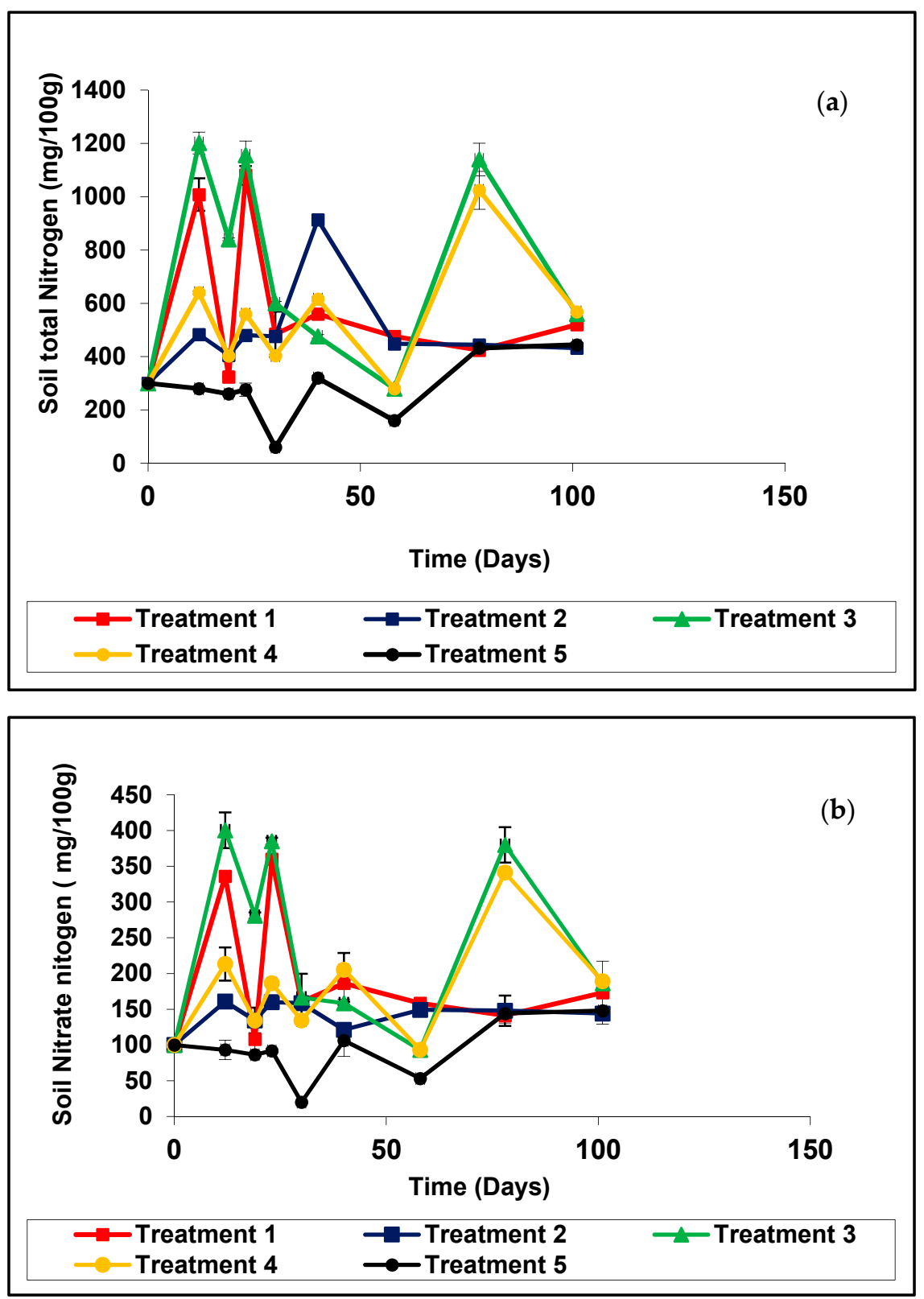

Figure 2. Variation of (a) total nitrogen in soil with different treatments; (b) nitrate nitrogen in soil with different treatments in the pot experiment.

Nitrate- $\mathrm{N}$ in the soil of treatment 3 increased during the first 12 days and later on decreased gradually until days after planting and again increased. According to the mean separation, treatments 3,1 , and 4 had the highest total $\mathrm{N}$ with no significant difference among them while 5 showed the lowest total $\mathrm{N}$. The rice husk biochar coated urea and anaerobically digested rice straw compost amendment also caused a significant increase in the total plant $\mathrm{N}$ compared to control treatments. After three and half months, the soil $\mathrm{N}$ were as follows; treatment $1(0.248 \mathrm{~kg} / \mathrm{ha})$, treatment $2(0.207 \mathrm{~kg} / \mathrm{ha})$, treatment 3 $(0.260 \mathrm{~kg} / \mathrm{ha})$, treatment $4(0.247 \mathrm{~kg} / \mathrm{ha})$ and treatment $5(0.112 \mathrm{~kg} / \mathrm{ha})$. After three and half months, the soil nitrate-nitrogen were as follows; treatment $1(0.094 \mathrm{~kg} / \mathrm{ha})$, treatment $2(0.069 \mathrm{~kg} / \mathrm{ha})$, treatment $3(0.086 \mathrm{~kg} / \mathrm{ha})$, treatment $4(0.082 \mathrm{~kg} / \mathrm{ha})$ and treatment 5 $(0.037 \mathrm{~kg} / \mathrm{ha})$.

The $\mathrm{P}$ of the soil of treatment 1 decreased during the first 30 days and then gradually increased. $P$ in the soil of treatment 2 decreased during the first 19 days and then gradually 
increased (Figure 3a). P in the soil of treatment 3 decreased during the first 30 days and then gradually increased. $P$ in the soil of treatment 4 decreased during the first 23 days and then gradually increased.
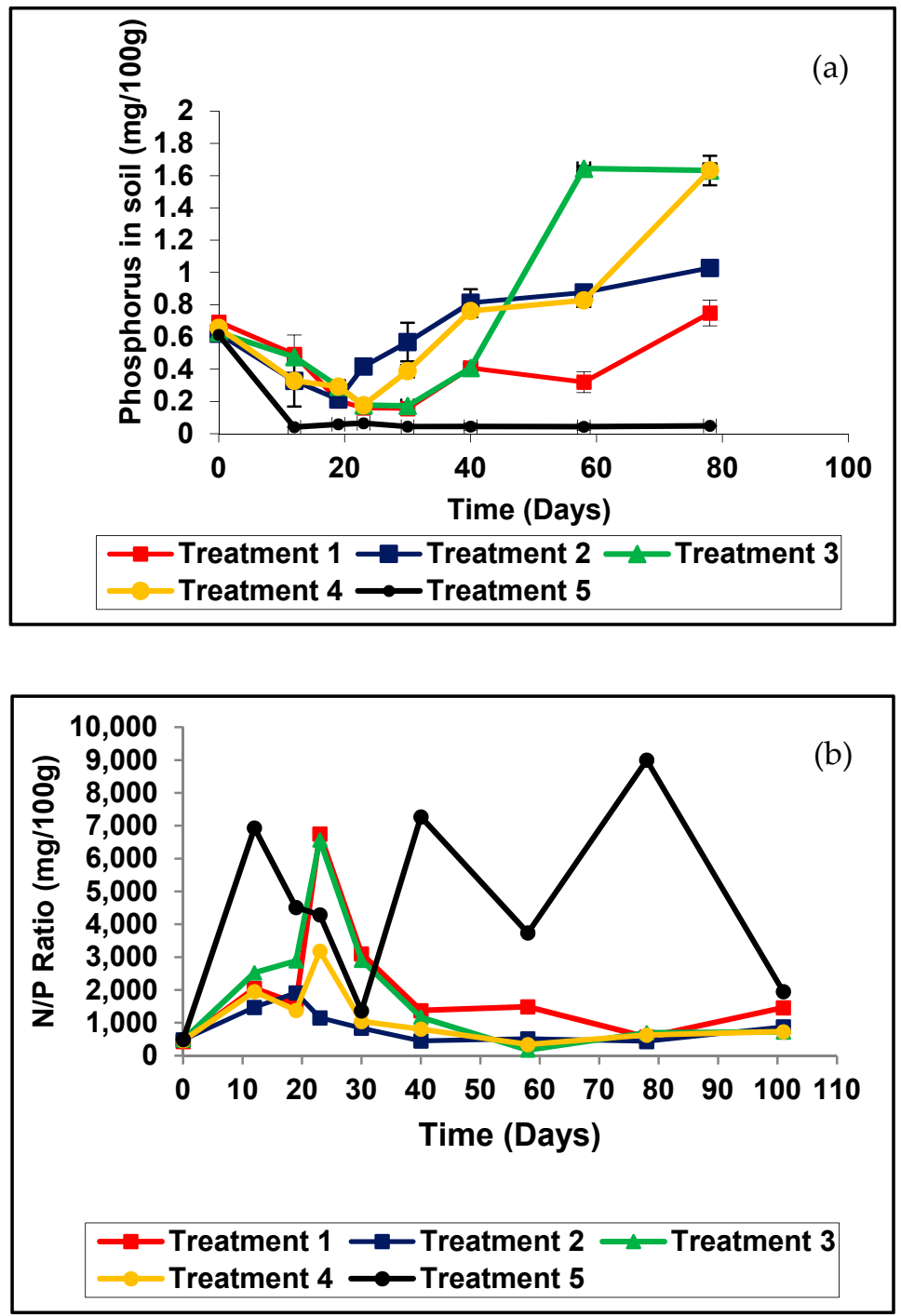

Figure 3. Phosphorus and N/P ratio variation. (a) Variation of phosphorus in soil with different treatments; (b). Influence of nitrogen on phosphorous uptake as illustrated with the ratio of nitrogen to phosphorus in the pot experiment. Each data point is a mean of four replicates. Treatment 1inorganic fertilizer only (Urea, TSP and MOP), Treatment 2- rice husk biochar coated Urea, TSP and MOP, Treatment 3- inorganic fertilizer (Urea, TSP and MOP) with anaerobically digested rice straw compost only, Treatment 4 - rice husk biochar Urea, TSP and MOP with anaerobically digested rice straw compost and Treatment 5- no fertilizer as control.

The rice husk coated urea (Treatment 2 ) and inorganic fertilizer with anaerobically digested rice straw compost amendment also caused a significant increase in the P compared to control treatments. After three and half months, the soil $\mathrm{P}$ were as follows; treatment 1 $(0.356 \mathrm{~kg} / \mathrm{ha})$ treatment $2(0.492 \mathrm{~kg} / \mathrm{ha})$, treatment $3(0.780 \mathrm{~kg} / \mathrm{ha})$, treatment $4(0.780 \mathrm{~kg} / \mathrm{ha})$ and treatment $5(0.228 \mathrm{~kg} / \mathrm{ha})$. Phosphorus amounts in the soil of treatment 3 and 4 were the highest when compared to treatment 1.

After three and half months, the soil K was as follows; treatment $1(23.52 \mathrm{~kg} / \mathrm{ha})$, treatment $2(23.88 \mathrm{~kg} / \mathrm{ha})$, treatment $3(24.72 \mathrm{~kg} / \mathrm{ha})$, treatment $4(24.08 \mathrm{~kg} / \mathrm{ha})$ and treat- 
ment $5(1.2 \mathrm{~kg} / \mathrm{ha})$. Considering the $\mathrm{pH}$ of the soil (Figure $4 \mathrm{~b})$ and organic matter content (Figure $4 \mathrm{c})$, treatment effects were not significant $(p<0.05)$.
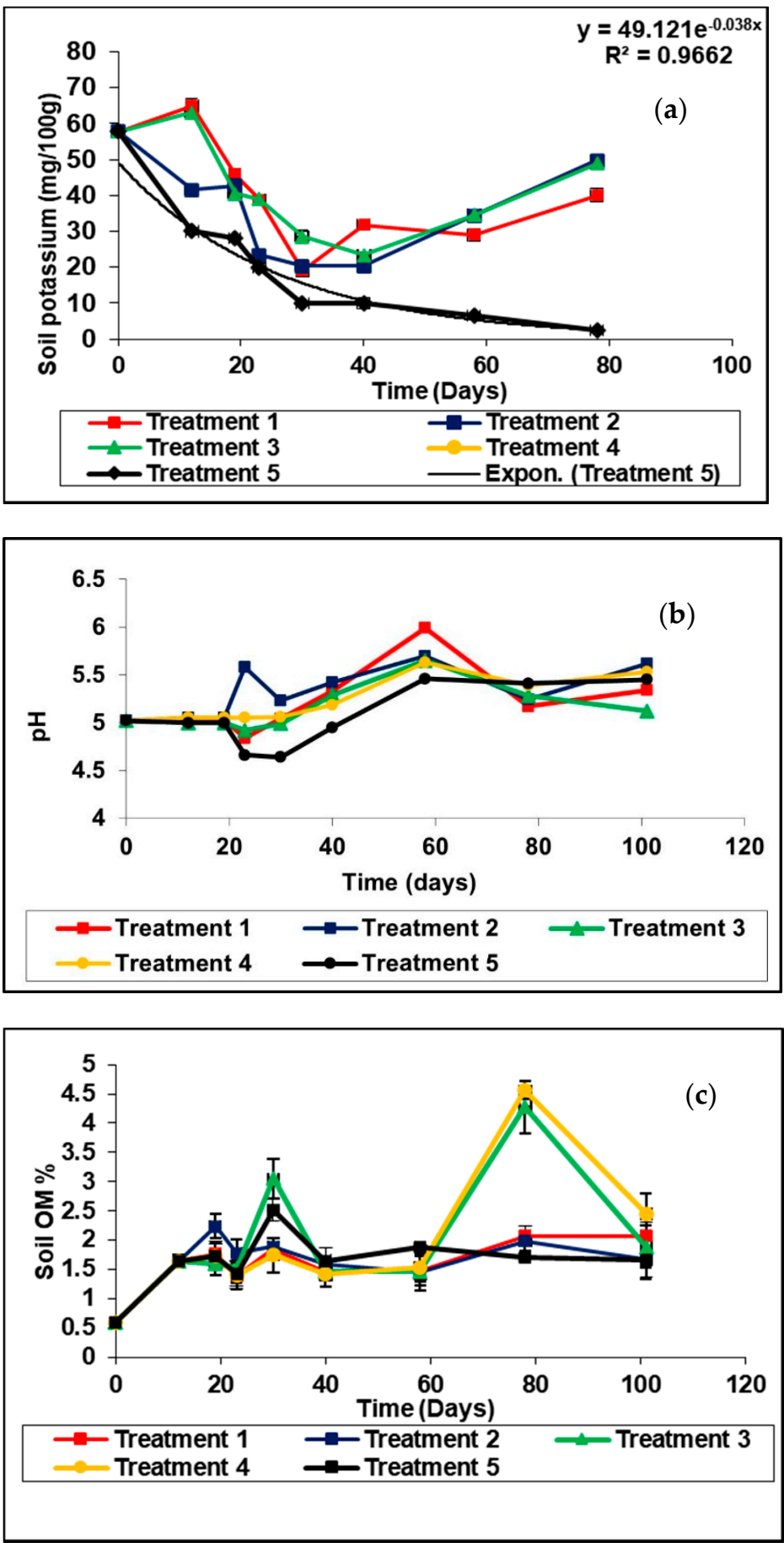

Figure 4. Variation of (a) potassium in soil with different treatments; (b) pH of the soil with different treatments; (c) organic matter of soil with different treatments in the pot experiment. Each data point is a mean of four replicates. Treatment 1 - inorganic fertilizer only (Urea, TSP and MOP), Treatment 2 - rice husk biochar coated Urea, TSP and MOP, Treatment 3- inorganic fertilizer (Urea, TSP and MOP) with anaerobically digested rice straw compost only, Treatment 4- rice husk biochar Urea, TSP and MOP with anaerobically digested rice straw compost and Treatment 5- no fertilizer as control. 


\subsection{Leaching Column Experiment}

Each data point represents the mean of two replicates. Treatment 1 -inorganic fertilizer only, Treatment 2-rice husk biochar coated urea only, Treatment 3-anaerobically digested rice straw compost, and Treatment 4 -no fertilizer as a control.

Figure 5 a shows that the $\mathrm{NO}_{3}-\mathrm{N}$ of leachates of treatment 1 increased during the first 14 days and gradually decreased and again increased. The $\mathrm{NO}_{3}-\mathrm{N}$ of leachates of treatment 2 increased to $48.4 \mathrm{mg} / \mathrm{L}$ during the first 14 days and decreased gradually and again increased. These fluctuations can be attributed to the application of urea at specified times responding to given dosages. In the case of compost, the $\mathrm{NO}_{3}-\mathrm{N}$ of leachates of treatment 3 increased during the first 47 days and then it decreased gradually $20.43 \mathrm{mg} / \mathrm{L}$. In the first week, leaching losses from treatment 3 were higher than treatment 1.
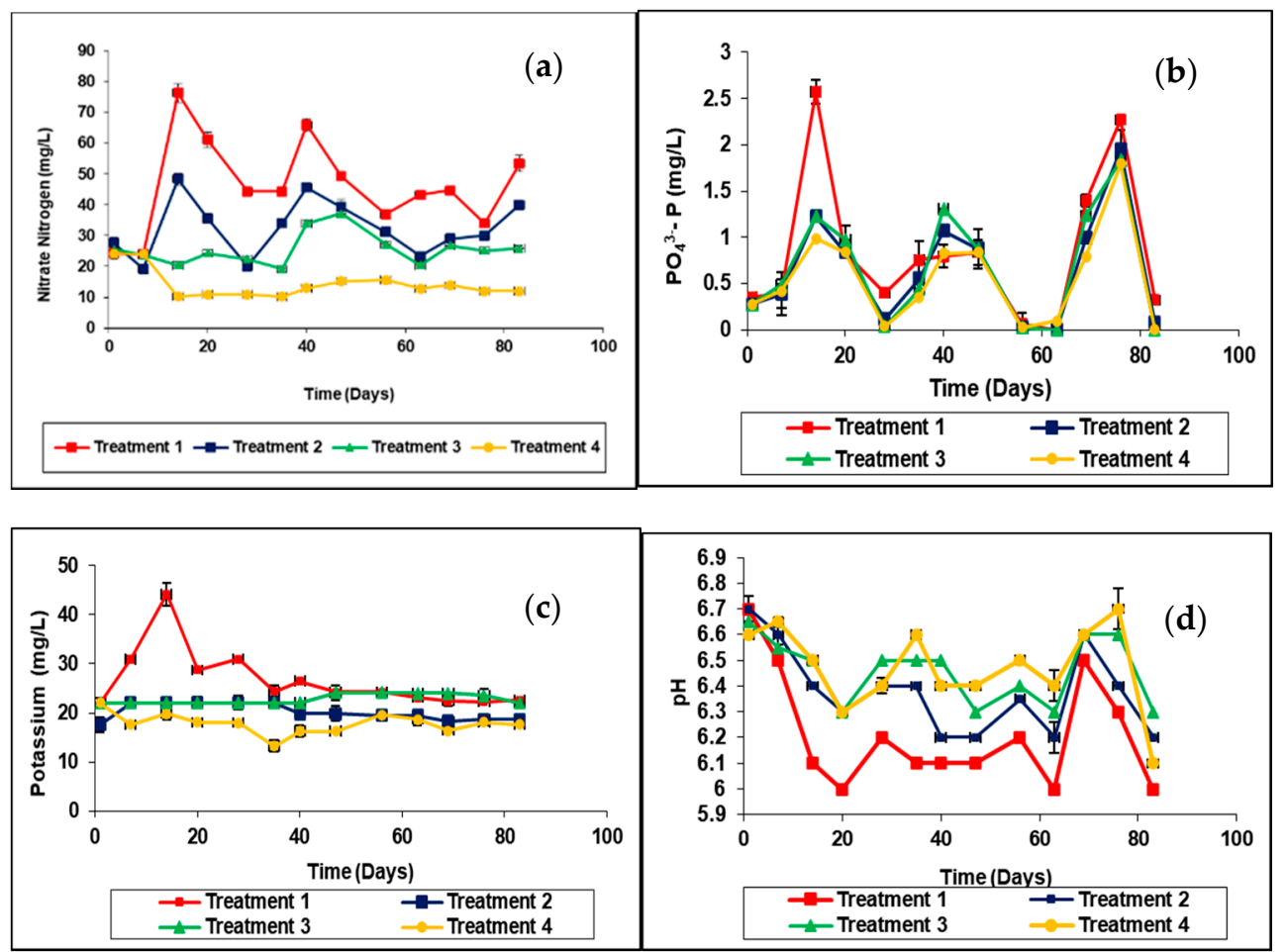

Figure 5. (a) Variation of $\mathrm{NO}_{3}{ }^{-}-\mathrm{N}$ with time; (b). Variation of $\mathrm{PO}_{4}{ }^{-3}-\mathrm{P}$ with time; (c). Variation of $\mathrm{K}+$ with time; (d). Variation of $\mathrm{pH}$ with time in the leaching column experiment.

According to the results of mean separation, the results of all the treatments are significantly different from each other $(p<0.0001)$. Treatment 1 has the highest value of $\mathrm{NO}_{3}-\mathrm{N}$ leaching and 2, 3, and 4 come in descending order (Figure 5a). According to Table 3 the cumulative $\mathrm{NO}_{3}{ }^{-}-\mathrm{N}$ leaching losses of kilogram per hectare (soil depth was $20 \mathrm{~cm}$ ). of different treatments were as follows; treatment 1 was $30.1 \pm 0.31 \mathrm{~kg} / \mathrm{ha}$, treatment 2 was $21.64 \pm 0.51 \mathrm{~kg} / \mathrm{ha}$, treatment 3 was $16.64 \pm 0.21 \mathrm{~kg} / \mathrm{ha}$ and treatment 4 control were $9.26 \pm 0.11 \mathrm{~kg} / \mathrm{ha}$. Treatment 1 has the highest value of $\mathrm{NO}_{3}{ }^{-}-\mathrm{N}$ leaching and 2, 3, and 4 come in descending order. Results reveal that biochar coated urea and rice compost have potential in terms of reducing groundwater pollution of $\mathrm{NO}_{3}{ }^{-}$due to leaching compared to treatment 1 (inorganic fertilizer only). 
Table 3. Leaching losses of the nutrients.

\begin{tabular}{ccccc}
\hline Nutrient & Treatment 1 & Treatment 2 & Treatment 3 & Treatment 4 \\
\hline $\mathrm{NO}_{3}-\mathrm{N}(\mathrm{kg} / \mathrm{ha})$ & $30.10^{\mathrm{a}} \pm(0.31)$ & $21.64^{\mathrm{b}} \pm(0.51)$ & $16.64^{\mathrm{c}} \pm(0.21)$ & $9.26^{\mathrm{d}} \pm(0.11)$ \\
$\mathrm{PO}_{4}-\mathrm{P}(\mathrm{kg} / \mathrm{ha})$ & $0.549^{\mathrm{a}} \pm(0.21)$ & $0.419^{\mathrm{b}} \pm(0.45)$ & $0.435^{\mathrm{b}} \pm(0.16)$ & $0.360^{\mathrm{b}} \pm(0.39)$ \\
$\mathrm{K}(\mathrm{kg} / \mathrm{ha})$ & $4.357^{\mathrm{a}} \pm(0.95)$ & $3.294^{\mathrm{b}} \pm(0.32)$ & $3.709 \mathrm{~b}^{\mathrm{c}} \pm(0.21)$ & $2.915^{\mathrm{c}} \pm(0.98)$ \\
$\mathrm{Gas}$ volume & $15,952.74^{\mathrm{a}} \pm$ & $8966.34^{\mathrm{b}} \pm$ & $8824.92^{\mathrm{b}} \pm$ & $7467.24^{\mathrm{b}} \pm$ \\
$\left(\mathrm{m}^{3} / \mathrm{ha}\right)$ & $(12.31)$ & $(15.64)$ & $(11.25)$ & $(14.56)$ \\
\hline
\end{tabular}

Mean followed by the same letter at each column are not significantly different $(p<0.05)$, each value represents the mean of two replicates. SD is given in parenthesis.

The cumulative leaching losses of $\mathrm{P}$ of eighty-three days of different treatments were as follows; treatment 1 was $10.98 \mathrm{mg} / \mathrm{L}(0.66 \%)$, treatment 2 was $8.39 \mathrm{mg} / \mathrm{L}(0.19 \%)$, treatment 3 was $8.7 \mathrm{mg} / \mathrm{L}(0.14 \%)$ and treatment 4 , control was $7.2 \mathrm{mg} / \mathrm{L}$. According to the cumulative addition of phosphorous to the columns except for the control, leaching losses of $P$ percentages are as follows; treatment 1 was $0.66 \%$, treatment 2 was $0.19 \%$ and treatment 3 was $0.14 \%$. Considering, P there are significant treatment effects (Figure $5 b$ ). According to Table 3 the cumulative $P$ leaching losses in different treatments were as follows; treatment 1 was $0.544 \mathrm{~kg} / \mathrm{ha}$, treatment 2 was $0.419 \mathrm{~kg} / \mathrm{ha}$, treatment 3 was $0.435 \mathrm{~kg} / \mathrm{ha}$ and treatment 4 control was $0.360 \mathrm{~kg} / \mathrm{ha}$. So, treatment 1 has the highest value of $\mathrm{P}$ leaching, and 2,3, and 4 come in descending order. Using biochar as a coating material of urea also can save the reduction loss of $\mathrm{P}$ biochar coated urea and rice straw compost has potential in terms of reducing groundwater pollution of $P$ due to leaching compared to treatment 1.

The cumulative leaching losses of $\mathrm{K}$ after eighty-three days of different treatments were as follows: treatment $1(346.64 \mathrm{mg} / \mathrm{L})$, treatment $2(262.36 \mathrm{mg} / \mathrm{L})$, treatment $3(296.48 \mathrm{mg} / \mathrm{L})$, and treatment 4 control $(231.94 \mathrm{mg} / \mathrm{L})$. According to the cumulative addition of potassium to the columns except for the control, leaching losses of $\mathrm{K}$ percentages are as follows; treatment 1 was $19.26 \%$, treatment 2 was $5.05 \%$ and treatment 3 was $17.78 \%$. According to the mean separation treatment, $1(4.375 \mathrm{~kg} / \mathrm{ha})$ showed the highest $\mathrm{K}$ followed by 3 ( $3.709 \mathrm{~kg} / \mathrm{ha}), 2(3.294 \mathrm{~kg} / \mathrm{ha})$, and $4(2.915 \mathrm{~kg} / \mathrm{ha})$. However, treatments 3 and 2 are not significantly different and again 2 and 4 are also not significantly different (Figure 5c). Treatments 4 and 3 have a higher $\mathrm{pH}$ than treatments 1 and 2 (Figure $5 \mathrm{~d}$ ).

\section{Discussion}

\subsection{Analysis of Soil Physicochemical Properties}

Soil physicochemical properties changes caused by cultural practices and their consequences to soil productivity have generated significant research concerns. Degradation of soil fertility and quality are key factors for declining yield [19]. Soil fertility must be maintained to sustain and improve crop growth and yield. Soil is puddled (mixes soil and water to produce an impervious layer) before rice transplanting and kept flooded to create anaerobic conditions for rice growth. After puddling create a plow layer. This plow layer reduces hydraulic conductivity to support water ponding. It minimized the water percolation losses and enhanced the water and nutrient use efficiency of rice [20]. Furthermore, puddling triggered several changes in soil physical properties such as breaking down soil aggregates and forming hardpans at a shallow depth. This hard fan led to induced changes in pore size distribution [21].

Under flooded conditions, the redox potential of paddy is low, and $\mathrm{NO}_{3}{ }^{-}, \mathrm{Fe}^{3+}, \mathrm{Mn}_{4}{ }^{+}$, and $\mathrm{SO}_{4}{ }^{2-}$ are, respectively, reduced to $\mathrm{NH}_{4}{ }^{+}, \mathrm{Fe}^{2+}, \mathrm{Mn}^{2+}$, and $\mathrm{S}^{2-}$. Thus, flooding also improves the availabilities of $\mathrm{P}, \mathrm{K}, \mathrm{Si}, \mathrm{Mo}, \mathrm{Cu}$, and $\mathrm{Co}$ and reduces the availabilities of $\mathrm{N}$, $\mathrm{S}$, and $\mathrm{Zn}$. the redox potential is increased, thereby oxidizing the soil nutrient elements, and changing the effectiveness of the above-mentioned elements [22]. In most lowland rice soils, $\mathrm{P}$ availability initially increased on flooding and rice may meet its $\mathrm{P}$ requirement from the residual $\mathrm{P}$ [23]. The efficiency of $\mathrm{K}$ fertilizer application is affected by various factors. Both rice and the subsequent crop remove enormous amounts of $\mathrm{K}$ as a byproduct, 
resulting in a significant negative $\mathrm{K}$ balance in soils regardless of whether $\mathrm{K}$ fertilizers are applied at recommended doses [24].

\subsection{Pot Experiment}

\subsubsection{Rice Plant Vegetative Growth}

The vegetative growth stage of rice has several phases. These phases are tillering, an increase in plant height, and leaf emergence at regular intervals. The length of this stage primarily determines the total life cycle duration of different rice varieties. Panicle initiation (PI) is the start of the reproductive phase of rice development that may occur before the maximum tiller number is reached in very-short duration and some short-duration varieties. Heading, when the panicle is fully visible stage rice varieties may be staggered due to later tillers that produce panicles. The maximum tiller (tillers develop in the axils of leaves, giving each plant three to a dozen or more) number is reached and followed by a vegetative lag phase before panicle initiation (PI) occurs [25]. In direct-seeded rice fields with a normal plant population (10 to 20 plants per square foot), rice plants generally produce 2 to 5 panicle bearing tillers per plant compared to 10 to 30 tillers per plant in transplanted rice where more space is available between plants. After maximum tillering has occurred, no more effective tillers are produced. A portion of the late tillers generally dies due to competition effects. The first yield component, potential panicles per unit area, is determined at this time [25]. Generally, the number of tillers is determined during the vegetative growth period and is mainly governed by the tillering capacity of cultivars, planting density, and the availability of mineral nutrition, particularly nitrogen [26]. Management of $\mathrm{N}$ fertilizer for maximum uptake efficiency by the rice crop varies with the cultural system, variety, soil texture, soil moisture, and several other factors. Correct management of the pre-flood $\mathrm{N}$ is critical since a rice crop's potential grain yield is determined by the early N. The number of panicles (heads) and the number of grains per panicle are determined by the pre-flood $\mathrm{N}$ application $[25,27,28]$. These results indicated that the importance of basal application of readily available inorganic fertilizers especially $\mathrm{N}$ fertilizers.

\subsubsection{Yield and Yield Component}

The reproductive stage is characterized by culm elongation, a rate of increase in tiller number, booting, the emergence of the flag leaf, heading, and flowering. The reproductive stage usually lasts approximately 60 days in most varieties. Panicle initiation is the time when the panicle primordia initiate the production of a panicle in the uppermost node of the culm. Panicle differentiation is closely associated with the internodal elongation stage. Panicle differentiation is equivalent at this point, the panicle is 1 to $2 \mathrm{~mm}$ in length and the branching of the panicle is visible. This is a critical stage during rice plant development and the environment can have a major effect on plant growth [25]. High temperatures tend to reduce the grain filling period and may reduce grain weight. Low temperatures tend to lengthen the time required for grain fill and ripening [25].

\subsubsection{Biomass Yield}

There is some evidence that biochar can reduce the run-off of agricultural inputs such as nitrates as well as suppress $\mathrm{N}_{2} \mathrm{O}$ and $\mathrm{CH}_{4}$ emission from the soil to the atmosphere [29-32]. In this way, biochar may act to improve the efficiency of the use of nitrogen in the soil. It is important to note that the properties of biochar in soils are dynamic due to the Physicochemical and biological changes which occur over time [29-32]. The addition of biochar to agricultural soil enhances soil properties such as water retention capacity, soil quality, soil organic matter stability, and nutrient retention capacity, maintaining soil acidity level, organic carbon sequestration, greenhouse gases emission reduction, and microbiological activity [14,15]. 


\subsubsection{Total Nitrogen and Nitrate Nitrogen in the Soil}

Most of the organic amendments supply low amounts of available $\mathrm{N}$ due to immobilization after organic matter decomposition and $\mathrm{N}$ mineralization. In addition, the $\mathrm{N}$ from organic matter is also involved in other soil processes such as nitrification and denitrification. The higher $\mathrm{N}$ uptake percentage in the treatment $3(0.20 \%)$ followed by 1 $(0.19 \%), 4(0.19 \%)$, and $2(0.179 \%)$ compared to the control $(0.128 \%)$ can be attributed to higher amounts of available $\mathrm{N}$ in the soil. Moreover, the addition of inorganic fertilizer with composted rice straw could facilitate decomposition due to relatively low lignin content. Due to its low $\mathrm{N}$ content, rice straw has a high $\mathrm{C} / \mathrm{N}$ which could induce $\mathrm{N}$ immobilization during decomposition in soil [28]. Biochar added plots receiving nutrients (NPK) sustained higher crop yield compared to control plots where yield declined rapidly. Results from semi-arid soils in Australia have shown a positive response to biochar in combination with fertilizer in pot trials [29]. A key consideration highlighted in several studies is the potential for biochar to immobilize previously plant-available $\mathrm{N}$. This could be from the mineralization of labile, high $\mathrm{C} / \mathrm{N}$ ratio of biochar drawing $\mathrm{N}$ into microbial biomass, sorption of ammonium, or sequestration of soil solution into fine pores [30].

\subsubsection{Phosphorus in Soil}

Soil solution $\mathrm{P}$ concentrations are relatively low, the quantity of $\mathrm{P}$ in the soil solution at a given time is generally on the order of $<1 \mathrm{~kg} / \mathrm{ha}$, or $1 \%$ of the total quantity of $\mathrm{P}$ in the soil [33]. Inorganic P occurs in soil, mostly in insoluble mineral complexes, some of them appearing after the frequent application of inorganic fertilizers. These insoluble, precipitated forms cannot be absorbed by plants [34]. Organic matter is also an important reservoir of immobilized $\mathrm{P}$ that accounts for $20-80 \%$ of $\mathrm{P}$ in soils [34]. Only $0.1 \%$ of the total $\mathrm{P}$ exists in a soluble form available for plant uptake [35] because of its fixation into an unavailable form due to $\mathrm{P}$ fixation. The addition of $\mathrm{P}$ to the soil as soluble commercial fertilizer or in the by-products causes an immediate increase in the P concentration of the soil solution (Figure 3a). This $\mathrm{P}$ then participates primarily in adsorption and precipitation processes, leading to fluctuating $\mathrm{P}$ values in the soil. Initially, these sorption processes are easily reversible and added $\mathrm{P}$ is readily available for plant uptake, susceptible to losses in runoff or leaching [33]. In the present pot experiment, there was no leaching or surface runoff. Overuse of $\mathrm{N}$ has not only caused low $\mathrm{N}$ use efficiency and soil acidification [36] but also resulted in a deleterious effect on rice quality, especially the appearance [37]. Figure $3 b$ illustrates the influence of the nitrogen to phosphorous ratio in soil indicates higher uptake of available nutrients. In all the four treatments, where nitrogen has been applied, the ratios showed a decreasing trend towards the end of the experiment. As reported by [38], it implies that freely available or excess nitrogen promotes the uptake of phosphorous. Although biochar in Treatment 2 had much less nitrogen, it was available to the rice plants with moderate levels of $\mathrm{P}$, in comparison to Treatments 3 and 4 , thus resulting in the lowest ratio. On the other hand, Treatment 4, performed similarly to Treatment 2 because of biochar, making nitrogen readily available with the added advantage of rice straw compost that would have supplied phosphorus, resulting in much higher yields. Note the variations of the control without inadequate P compared to nitrogen in the soil.

\subsubsection{Potassium in Soil}

Potassium $(\mathrm{K})$ is a macronutrient taken up by plants in large quantities. Potassium performs important roles such as enzyme activation, photosynthesis, photosynthate translocation, protein synthesis (i.e., nitrogen use), and plant water relations [6]. The potassium of soil of treatments 3 and 4 was the highest as compared to treatment 1, which contains NPK only. It could be attributed to the addition of compost at the beginning and during the growing period of the crop. A negative exponential function of the form $K=K_{0} e^{-\alpha t}$ could be fitted to the variation of soil $\mathrm{K}$ in treatment 5 . (Figure $4 \mathrm{a}$ ), where $\mathrm{K}$ and Ko are potassium concentration at time $t$ and initial concentration $(57.88 \mathrm{mg} / 100 \mathrm{~g})$, respectively and $\alpha(0.47)$ is the adsorption coefficient of potassium in the soil. The trend line can be 
observed as shown in Figure 5 simulation. In all other treatments, precipitations of K have taken place with desorption coefficients of exponential functions soon after 40 days had lapsed. This result implies that the $\mathrm{K}$ levels remain high due to compost applications and bio-char additions even for the following season. A lower level of $\mathrm{K}$ concerning those treatments was found to be the case for the inorganic conventional system in Treatment 1 , necessitating $\mathrm{K}$ applications for the next cropping season.

Because in the present pot experiment there was no leaching or surface runoff, when incorporated into soil substrate in pot trials, biochar, and local organic fertilizers altered the soil physical structure (bulk density) and modified the soil chemical properties ( $\mathrm{pH}, \mathrm{CEC}$, and $\mathrm{N}, \mathrm{P}$ and $\mathrm{K}$ supply). Low $\mathrm{pH}$ can limit plant growth by modifying the dynamic of crop nutrients. Hence, biochar addition could be particularly beneficial in acidic soils [39].

\subsubsection{Soil $\mathrm{pH}$ and Soil Organic Matter}

The addition of organic matter to flooded soil raises the $\mathrm{NH}_{4}^{+}$concentration of floodwater and leads to a $\mathrm{pH}$ increase [40]. Decreasing soil $\mathrm{pH}$ following organic materials can be partially attributed to the high release of organic acids causing mobilization of native calcium present $\mathrm{CaCO}_{3}$ in the soil. According to Agusalim et al. [41], organic C content in rice husk biochar is lower than that of rice straw. The highest level of soil organic matter was observed in rice husk biochar treated soil. This phenomenon indicated the recalcitrant nature of carbon in rice husk biochar as has been suggested by many researchers $[42,43]$.

\subsection{Leaching Column Experiment}

\subsection{1. $\mathrm{NO}_{3}{ }^{-}-\mathrm{N}$ in the Leachate}

Organic carbon decomposition by microbial activity influences many processes of the nitrogen cycle. With time, nitrogen concentration decreased due to microbial utilization of nitrate compounds and denitrifying as ammonia gas [44]. Anaerobically digested rice straw compost had readily available $\mathrm{NO}_{3}{ }^{-}-\mathrm{N}$. Management of urea-containing fertilizers requires a clear understanding of the reactions that urea undergoes when added to the soils. Urea is hydrolyzed to ammonia and carbon dioxide through the action of a soil urease enzyme. In most soils, urea hydrolysis occurs rapidly after urea-containing fertilizers are applied. Available $\mathrm{N}$ in organic sources is present in $\mathrm{NH}_{4}+$ or $\mathrm{NO}_{3}{ }^{-}$form but in amide form in urea. Hydrolysis of urea takes 1-2 weeks [45]. The cumulative $\mathrm{NO}_{3}{ }^{-}-\mathrm{N}$ leaching losses of eightythree days of different treatments were as follows; treatment 1 was $602.16 \mathrm{mg} / \mathrm{L}$, treatment 2 was $423.28 \mathrm{mg} / \mathrm{L}$, treatment 3 was $332.28 \mathrm{mg} / \mathrm{L}$ and treatment 4 control was $185.24 \mathrm{mg} / \mathrm{L}$. According to the cumulative addition of nitrogen to the columns except for the control, leaching loss of $\mathrm{NO}_{3}{ }^{-}-\mathrm{N}$ percentages is as follows; treatment 1 was $65.7 \%$, treatment 2 was $41.2 \%$ and treatment 3 was $21.8 \%$. The efficiency of the urea- $\mathrm{N}$ in rice culture is very low, generally around 30-40\%, in some cases even lower [46]. The application of urea was $110 \mathrm{~kg} /$ ha. Concerning the treatment 1 inorganic fertilizer, the percentage $\mathrm{NO}_{3}{ }^{-} \mathrm{N}$ leaching losses was $26.07 \%$. One-fourth of the $\mathrm{N}$ is in the nitrate form and is subject to loss by leaching or denitrification [47]. The application of biochar to soil could increase soil fertility and crop productivity by reducing leaching. However, the effects of biochar on nutrient leaching and organic carbon retention have been reported to vary with the applied biochar pyrolysis temperature, raw material, and soil type [15].

\subsection{2. $P$ in the Leachate}

Microorganisms also play a central role in the natural phosphorus cycle. The use of phosphate solubilizing microorganisms plays a vital role in solubilizing the insoluble forms of phosphorus. Soil microorganisms act as sink and source of phosphorus (P) and mediate key processes in the soil P cycle, e.g., P mineralization and immobilization [48]. The fluctuations of phosphate may have cyclic effects which were 28 days (Figure $5 \mathrm{~b}$ ). The rate increased gradually to a peak and then reduced to lower values. It can be mathematically expressed as logistic growth equations, applicable for microbial growth and decay. The microbial cyclic effects have been recorded by $[49,50]$. This cycle occurs utilizing the cyclic 
oxidation and reduction of phosphorus compounds, where electron transfer reactions between oxidation stages range from phosphine to phosphate. The genetic and biochemical mechanisms of these transformations are not yet completely understood [51].

\subsection{3. $\mathrm{K}$ in the Leachate}

According to Table 3, the cumulative $\mathrm{K}$ leaching losses of kilogram per hectare of different treatments were as follows; treatment 1 was $17.33 \mathrm{~kg} / \mathrm{ha}$, treatment 2 was $13.18 \mathrm{~kg} / \mathrm{ha}$, treatment 3 was $14.82 \mathrm{~kg} / \mathrm{ha}$ and treatment 4 control was $11.59 \mathrm{~kg} / \mathrm{ha}$. Treatment 1 has the highest value of $\mathrm{K}$ leaching and 2, 3, and 4 come in descending order. Using biochar as a coating material of urea also saves the reduction loss of $\mathrm{K}$. Biochar coated urea and rice straw compost have potential in terms of reducing groundwater pollution of $\mathrm{K}$ due to leaching compared to treatment 1 .

\subsection{4. $\mathrm{pH}$}

There are also relationships between fertilizer application and $\mathrm{NO}_{3}{ }^{-}-\mathrm{N}$ and $\mathrm{PO}_{4}{ }^{3-}-\mathrm{P}$ leaching and $\mathrm{pH}$. The maximum uptake of most nutrients occurs at a soil $\mathrm{pH}$ near neutral. The availability of most macronutrients such as nitrogen, phosphorus, potassium, sulfur, calcium, and magnesium, decreases as soil acidity increases. The relationship between soil $\mathrm{pH}$ and nutrient uptake efficiency is that fertilizer use, and crop response are expected to change as a function of soil $\mathrm{pH}[52]$.

\section{Materials and Methods}

\subsection{Preparation of Slow-Releasing Nitrogen Fertilizer}

Biochar was produced from rice husk [53]. The pyrolizer was designed to produce biochar. The pyrolizer consists of the following main components; i. Hopper for feedstock ii. Feeding mechanism iii. Combustion chamber (hollow cylindrical retort) iv. Charcoal collector v. Torch. The reactor was loaded with $160 \mathrm{~kg}$ rice husk. Then by using the feeder, a filled column of rice husk $(20 \mathrm{~kg})$ was obtained. Coconut husk and shells which were filled into the charcoal collector was used as a fuel source. It was fired from the charcoal remover. Once ignition had taken place, an airstream was introduced using a centrifugal blower. The quantity of air was regulated by the inlet valve. The torch was used, and an airstream was introduced into the inclined cylindrical chamber through the air inlet. Pyrolysis of rice husk takes place in the inclined chamber (Temperature, $550^{\circ} \mathrm{C}$ ), and hence, it is performed as an inclined flow reactor (Figure 6). The average temperature depends on the air mixing ratio of the incline chamber. A temperature measuring pyrometer probe was inserted into the reactor chamber and got the temperature. In this method, the quantity of feedstock, time taken to produce charcoal were measured and recorded. After cooling the reactor to room temperature, the char was collected from the reactor.
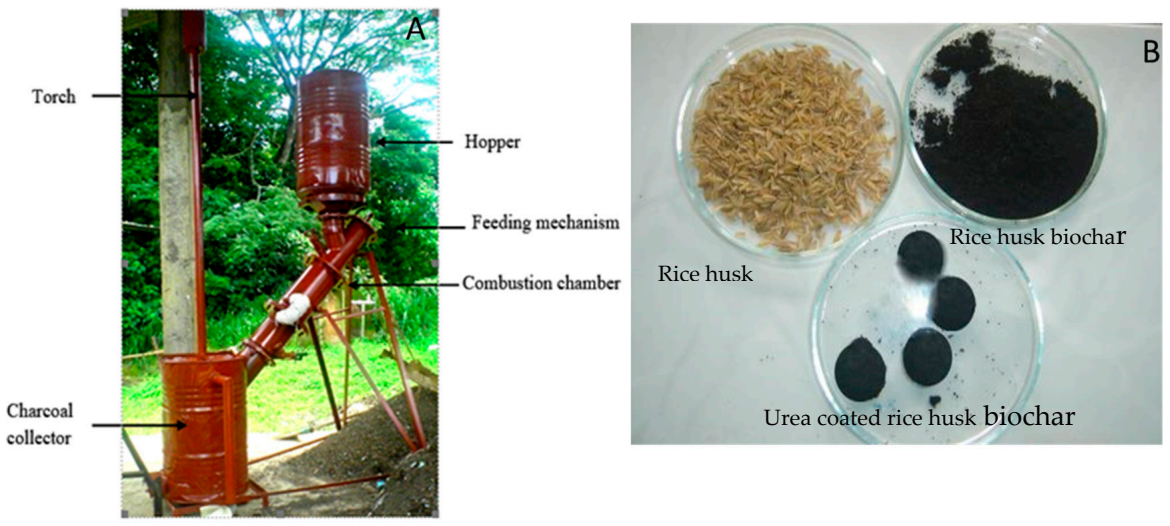

Figure 6. The material used for the biochar production and urea coated biochar generated. A. Pyrolizer; B. Slow releasing nitrogen fertilizer prepared using biochar. 
Rice husk was partially burnt, ground, sifted through sieve no $60(250 \mu \mathrm{m})$ and obtained a fine powder. This fine powder was used as a coating material for urea. Carbon powder and urea were mixed thoroughly and with the help of cassava starch. Granules of $1.0 \mathrm{~cm}$ diameter were formed manually. Production of $1 \mathrm{~kg}$ of slow-releasing fertilizer mixture having a ratio of biochar: urea (2:1). As a binding agent 30-50 g of dried cassava starch was used (cassava boiled dried ground). Sodium hydroxide can be added about $3 \%$ of the weight of starch to enhance the strength and binding quality. After making carbon-coated urea balls, they were kept in a desiccator for about three days. The nitrogen content of urea was $46 \%$ and $0.3 \%$ in rice husk biochar (Figure 6).

\subsection{Experimental Site for the Pot Experiment}

A pot experiment was conducted in the Yala season at the Meewathura Farm, Department of Agricultural Engineering, Faculty of Agriculture, University of Peradeniya, Sri Lanka. Soil samples were collected from a farmer's field at Megoda Kalugamuwa, Sri Lanka at depths of up to $20 \mathrm{~cm}$, and then dried, ground, and passed through a $2.0 \mathrm{~mm}$ sieve. The soil samples were analyzed for total nitrogen, phosphorus, potassium, and soil samples were analyzed for organic matter, $\mathrm{pH}, \mathrm{EC}$, and Eh [54].

\subsection{Pot Experiment}

Soil samples were collected from a farmer's field at Megoda Kalugamuwa, Sri Lanka at depths of up to $20 \mathrm{~cm}$, and then dried, ground, and passed through a $2.0 \mathrm{~mm}$ sieve. Fifteen $\mathrm{kg}$ of soil was placed each into twenty plastic pots (size of the pot $30 \mathrm{~cm}$ diameter and $45 \mathrm{~cm}$ height) and the pots were tapped several times to settle the soil. Soils were saturated with water and allowed for one week to reach equilibrium. Rice seedlings (Bg 358) grown on Petri dishes for one week were planted in each pot (three plants per pot). The treatments were set up in a completely randomized design: Five treatments were used for twenty pots each replicated four times (Table 4).

Table 4. Treatments were carried out in this study.

\begin{tabular}{|c|c|}
\hline Treatment Number & Fertilizer Mixture \\
\hline 1 & Inorganic fertilizer only (Urea, TSP, and MOP) \\
\hline 2 & Rice husk biochar coated urea, TSP, and MOP \\
\hline 3 & $\begin{array}{c}\text { Inorganic fertilizer (Urea, TSP, and MOP) with anaerobically } \\
\text { digested rice straw compost }[55,56] \text { only }\end{array}$ \\
\hline 4 & $\begin{array}{l}\text { Rice husk biochar coated urea, TSP, and MOP with anaerobically } \\
\text { digested rice straw compost anaerobic digestion }[55,56]\end{array}$ \\
\hline 5 & No fertilizer added \\
\hline
\end{tabular}

Before the fertilizers were applied, the water level in each pot was maintained at $2 \mathrm{~cm}$ from the soil surface to ensure that the system was waterlogged. The water level was marked on the pots. The water level in the pots was maintained (for the vegetative growth period) by adding water as the deficit of the original water level. The fertilizers were applied to the soil surface. Urea (46 g N/100 g), TSP (20 g P/100 g), and MOP (60 g K/100 g) were applied to all pots, except the control based on the Department of Agriculture (2009) recommendation. Rice husk biochar contains $0.58 \mathrm{~g} \mathrm{~N} / 100 \mathrm{~g}, 0.12 \mathrm{~g} \mathrm{P} / 100 \mathrm{~g}$, and $0.2 \mathrm{~g} \mathrm{~K} / 100 \mathrm{~g}$ while rice straw compost $0.98 \mathrm{~g} \mathrm{~N} / 100 \mathrm{~g}, 0.6 \mathrm{~g}$ P/100 $\mathrm{g}$ and $1.32 \mathrm{~g} \mathrm{~K} / 100 \mathrm{~g}$ respectively. In the case of treatments 2 and 4, one-third of urea from the recommended amount (Urea: biochar- 1:2) per pot was applied. It was assumed that in treatments 2 and 4, rice husk biochar would help to reduce leaching losses of urea. Zinc Sulphate at the rate of $3.92 \mathrm{mg}$ per pot was applied. Rice straw compost was applied at the rate of 2 tons/ha to treatments 3 and 4 twice during the cropping season. Compost additions to soil have the potential to contribute to the improvement of soil physical properties and fertility of the soil. 


\subsection{Soil Characterization and the Measurement of Agronomic Parameters of Rice Plants}

Two undisturbed soil samples of about $50 \mathrm{~g}$ were taken for bulk density and soil water determination, and a disturbing sample of about $100 \mathrm{~g}$ was taken for analysis of chemical properties. The soil samples were collected once a week after the application of basal dressing over three months. Soil texture, $\mathrm{pH}, \mathrm{EC}$, Eh, organic carbon, available $\mathrm{P}$, total $\mathrm{N}$, and exchangeable $\mathrm{K}$ were determined using standard soil analytical methods [54]. Herbicides or insecticides were not added to the treatments. Weed control was done manually. The number of tillers per hole was counted at the maximum stage of forming tillers ( 45 days after planting). Plant heights were measured once a week. Before harvesting, the number of panicles per hill was counted. At the time of harvesting 10 randomly selected rice plants were uprooted from each plot and roots were thoroughly washed and kept inside an oven at $70{ }^{\circ} \mathrm{C}$ for 3 days for dry weight determination of both below and above-ground biomass. At maturity, plots were harvested discarding the border rows and the grain yield of each plot was recorded at $14 \%$ moisture content. Three months after planting, plants were uprooted, and soils attached to roots were removed using running water and plants were oven-dried at $80^{\circ} \mathrm{C}$ for $72 \mathrm{~h}$ and dry weight was recorded.

\subsection{Leaching Column Experiment}

Two sets of leaching columns were prepared using $1.2 \mathrm{~m}$ tall polyvinyl chloride (PVC) pipes with a diameter of $0.15 \mathrm{~m}$ (Figure 7). Gas measuring and leachate recirculation orifices were made at the top of the column. The gas collection was done by using polythene tubes. A sampling port was attached to the bottom end of the column cap, and it was closed until getting the samples.

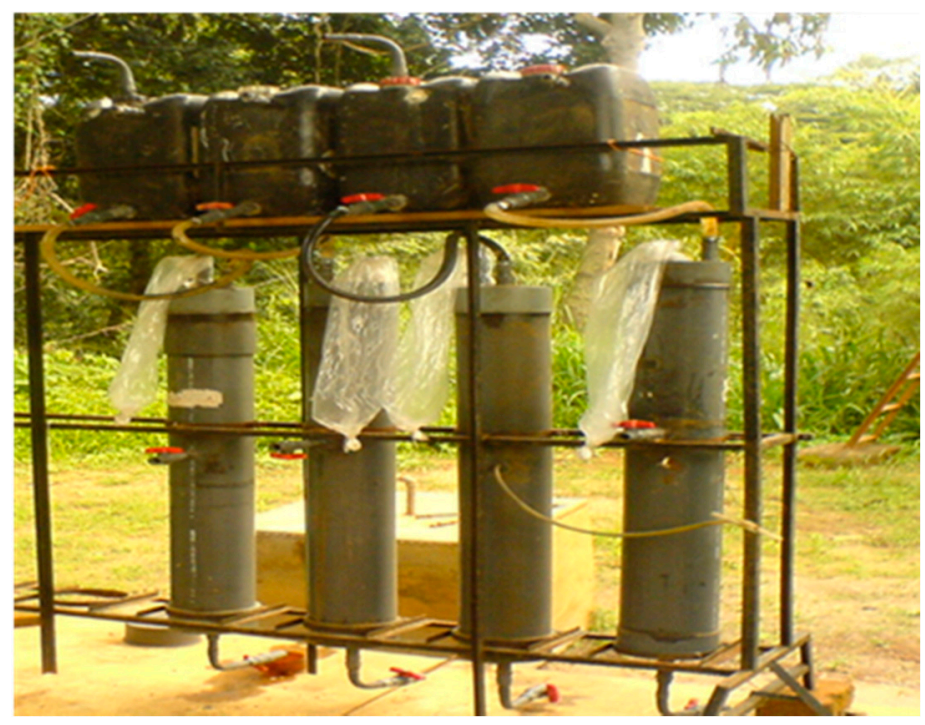

Figure 7. Setup of leaching columns.

There was a plastic container connected to the system to maintain a constant height of water $(5 \mathrm{~cm})$. Four PVC pipes of $1.2 \mathrm{~m}$ high and $0.15 \mathrm{~m}$ diameter were used to make leaching columns. A $40 \mathrm{~mm}$ thick layer of pre-cleaned, washed, and dried gravel with a particle size of 5-7.5 cm was used as the filter medium. Rice soil was taken from the Megoda Kalugamuwa, Kandy, Sri Lanka.

Every column was filled with $15 \mathrm{~kg}$ of rice soils (bulk density of $1.3 \mathrm{~kg} / \mathrm{m}^{3}$ ) as a substrate and the columns were saturated with water for 2 weeks. Table 5 Shows the four treatments were used for the columns as follows: 
Table 5. Treatments were carried out in this study.

\begin{tabular}{cc}
\hline Treatment Number & Fertilizer Mixture \\
\hline 1 & Inorganic fertilizer only (Urea, TSP, and MOP) \\
2 & Rice husk biochar coated urea, TSP and MOP only \\
3 & Anaerobically digested rice straw compost $[55,56]$ \\
4 & No fertilizer as a control \\
\hline
\end{tabular}

According to the Department of Agriculture (2009) recommendations, fertilizer for $31 / 2$ months variety was used for the columns except for the control. The Department of Agriculture (2009) recommendation was, $110 \mathrm{~kg} /$ ha of urea- (Basal dressing 10 and top dressing, 30, 50, and $20 \mathrm{~kg} / \mathrm{ha}$ after 3, 5, 7, and 8 weeks after planting, respectively). $50 \mathrm{~kg} / \mathrm{ha}$ of TSP, for basal dressing only, $80 \mathrm{~kg} / \mathrm{ha}$ of MOP- basal, and 8 weeks after planting (30 and $30 \mathrm{~kg} / \mathrm{ha}$, respectively). ZnSO4, $5 \mathrm{~kg} / \mathrm{ha}$. Same amounts of N, P, and K were applied for each column surface area. The $100 \mathrm{ml}$ leachates were obtained (once a week for 12 weeks period) from the leaching columns. Nitrate Nitrogen, phosphate phosphorus, potassium, and $\mathrm{pH}$ were determined using standard soil analytical methods [20]. A completely randomized design was used for this experiment.

\subsection{Statistical Analyses}

Analysis of variance (ANOVA) was performed and differences in mean values were determined using $t$-test at $p<0.0001$ and employing ANOVA and least significance difference procedures (SAS Institute (2011) SAS/STAT User's Guide (Version 9.2). Statistical Analysis System Inst, Cary, NC, USA).

\section{Conclusions}

Concerning the pot experiment, rice grain yield was significantly higher in rice husk biochar coated urea, TSP, and MOP with anaerobically rice straw compost. (Treatment 4) applied to the soil. The lowest yield was observed in the control (treatment 5 . Considering the $\mathrm{pH}$ of the soil and organic matter content of the pot experiment, treatment effects were not significant. The cyclic effect of phosphate release is an important finding, and it could be the central issue in defining microbial behavior in soils. The change of phosphate may have 28-day cyclic effects. Biochar can be used as a soil amendment and organic fertilizer, but adjustment of $\mathrm{pH}$ was required at high application rates. Rice husk biochar coated urea can potentially be used as a slow-releasing nitrogen fertilizer which reduces leaching of urea. Furthermore, the urea coating with biochar is less costly and helps to reduce the fertilizer cost ( $70 \%$ of urea cost) and contribute to mitigating pollution of water bodies. The addition of biochar to the soil significantly increased the soil properties such as $\mathrm{pH}$, electrical conductivity, organic matter, available phosphorus, available potassium, and the $\mathrm{C} / \mathrm{N}$ ratio. Biochar could act as a nutrient source and release nutrients such as $\mathrm{N}, \mathrm{P}$, and K. Rice straw and rice husks are rich in silicon. Carbonized straw or husk is used as a good silicon fertilizer. Silicic acid from the carbonized material, dissolved in the soil solution and can be adsorbed to soil minerals. Biochar application with the compost should be considered as an environmental and efficient agricultural practice for sustainable soil management in the agricultural ecosystem.

Author Contributions: Conceptualization: A.G., B.B. and O.M.; Investigation: A.G., B.B. and J.D.C.; Formal analysis: B.B., J.D.C. and A.G., Software: A.G. and O.M.; Methodology: A.G., J.D.C. and O.M.; Supervision: A.G.; Writing-A.G., B.B. and J.D.C.; Review \& Editing-A.G., B.B., J.D.C. and O.M. All authors have read and agreed to the published version of the manuscript.

Funding: This research received no external funding.

Informed Consent Statement: Not applicable.

Data Availability Statement: Not applicable. 


\begin{abstract}
Acknowledgments: The authors sincerely acknowledge D.D.K. Galahitiyawa, Staff technical officer and D.M.A.S. Wasantha Kumari, Department of Agricultural Engineering, H.M. S.S. C.H. Thundeniya, staff technical officer, Department of Animal Science and B.G.G. Wijesooriya, technical assistant Department of Crop Science, Faculty of Agriculture, University of Peradeniya, Sri Lanka for providing technical support to conduct this study.
\end{abstract}

Conflicts of Interest: The authors declare no conflict of interest.

\title{
References
}

1. Department of Census and Statistics. Available online: http://www.statistics.gov.lk/agriculture (accessed on 2 November 2021).

2. Herath, H.M.; Jayasinghe-Mudalige, U.K.; Silva, A.P.; Jayakodi, J.A.; Jayathilake, H.A.; Dharmakeerthi, R.S.; Dandeniya, W.S. An Empirical Investigation into the Policy Instruments to Promote Eco-friendly Technologies Replacing Chemical Fertilizer Use in Paddy Farming in Sri Lanka. SLJoT 2021, 2, 18-22.

3. Marambe, B.; Nissanka, S. Sri Lanka Status Report on Sustainable Nitrogen Management, Ministry of Mahaweli Development and Environment of Sri Lanka; Ministry of Mahaweli Development and Environment, Sri Lanka: Sri Jayawardenepura Kotte, Sri Lanka, 2019.

4. Bawatharani, T.; Mowjood, M.I.M.; Dayawansa, N.D.K.; Kumaragamage, D. Nitrate Leaching as a Function of Fertilization and Irrigation Practices in Sandy Regosols. Trop. Agric. Res. 2004, 16, 172-180.

5. Wallace, A.J.; Armstrong, R.D.; Grace, P.R.; Scheer, C.; Partington, D.L. Nitrogen use efficiency of $15 \mathrm{~N}$ urea applied to wheat based on fertilizer timing and use of inhibitors. Nutr. Cycl. Agroecosyst. 2019, 116, 41-56. [CrossRef]

6. Mardamootoo, T. Phosphorus management issues for crop production: A review. Afr. J. Agric. Res. 2021, 17, 939-952.

7. Nielsen, R.L. N Loss Mechanisms and Nitrogen Use Efficiency. In Purdue Nitrogen Management Workshops; Purdue University: West Lafayette, IN, USA, 2006; pp. 1-5.

8. He, Y.; Lehndorff, E.; Amelung, E.; Wassmannb, R.; Albertob, M.C.; Unoldd, G.; Jan Siemense, J. Drainage and leaching losses of nitrogen and dissolved organic carbon after introducing maize into a continuous paddy-rice crop rotation. Agric. Ecosys. Environ. 2017, 249, 91-100. [CrossRef]

9. Bodirsky, B.L.; Popp, A.; Lotze-Campen, H.; Dietrich, J.P.; Rolinski, S.; Weindl, I.; Schmitz, C.; Müller, C.; Bonsch, M.; Humpenöder, F.; et al. Reactive nitrogen requirements to feed the world in 2050 and potential to mitigate nitrogen pollution. Nat. Commun. 2014, 5, 3858. [CrossRef] [PubMed]

10. Mikunthan, T.; De Silva, C.S. Nitrate Pollution in Ground Water: A Case Study in Thrunelvely and Kondavil in Jaffna District. The Water Resources Research in Sri Lanka. In Symposium Proceedings of the Water Professionals' Day, Peradeniya, Sri Lanka; Dayawansa, N.D.K., De Silva, R.P., Eds.; Faculty of Engineering Technology: Sri Lanka, Nugegoda, 2008; pp. 27-28.

11. Kuruppuarachchi, D.S.P.; Fernando, W.A.R.N. Impact of agriculture on ground water quality: Leaching of fertilizers to ground water in Kalpitiya Peninsula. J. Soil Sci. Soc. Sri Lanka 1999, 11, 9-16.

12. Clune, J.W.; Crawford, J.K.; Boyer, E.W. Nitrogen and Phosphorus Concentration Thresholds toward Establishing Water Quality Criteria for Pennsylvania, USA. Water 2020, 12, 3550. [CrossRef]

13. Lehmann, J.; Joseph, S. Biochar for Environmental Management: Science and Technology and Implementation; Earthscan: London, UK, 2009.

14. Ayaz, M.; Feizien, D.; Tilvikien, V.; Akhtar, K.; Stulpinait, U.; Iqbal, R. Biochar Role in the Sustainability of Agriculture and Environment. Sustainability 2021, 13, 1330. [CrossRef]

15. Huang, D.; Liu, L.; Zeng, G.; Xu, P.; Huang, C.; Deng, L.; Wang, R.; Wan, J. The effects of rice straw biochar on indigenous microbial community and enzymes activity in heavy metal-contaminated sediment. Chemosphere 2017, 174, 545-553. [CrossRef]

16. Basnayake, B.F.A. Patent of Discovery of a Process to Retard the Release of Nitrogen Fertilizer by Using Charcoal and Manioc. Patent No. 10665, 1994.

17. Cao, X.D.; Ma, L.N.; Gao, B.; Harris, W. Dairy-Manure Derived Biochar Effectively Sorbs Lead and Atrazine. Environ. Sci. Technol. 2009, 43, 3285-3291. [CrossRef] [PubMed]

18. Jones, D.L.; Edward-Jones, G.; Murphy, D.V. Biochar mediated alterations in herbicide breakdown and leaching in soil. Soil Biol. Biochem. 2011, 43, 804-813. [CrossRef]

19. Ladha, J.K.; Dawe, D.; Pathak, H.; Padre, A.T.; Yadav, R.L.; Bijay, S.; Singh, Y.; Singh, Y.; Singh, P.; Kundu, A.L.; et al. How extensive are yield declines in long-term rice-wheat experiments in Asia? Field Crops Res. 2003, 81, 159-180. [CrossRef]

20. Mousavi, S.F.; Yousefi-Moghadam, S.; Mostafazadeh-Fard, B.; Hemmat, A.; Yazdani, M.R. Effect of puddling intensity on physical properties of silty clay soil under laboratory and field conditions. Paddy Water Environ. 2009, 7, 45-54. [CrossRef]

21. Behera, B.K.; Varshney, B.P.; Goel, A.K. Effect of puddling on puddled soil characteristics and performance of self-propelled transplanter in rice crop. Agric. Eng. Int. 2009, 10, 20-25.

22. Fan, M.S.; Jiang, R.F.; Zhang, F.S.; Lu, S.H.; Liu, X.J. Nutrient management strategy of paddy rice-upland crop rotation system. Chin. J. Appl. Ecol. 2008, 19, 424-432.

23. Gupta, R.K.; Ladha, J.K.; Singh, J.; Singh, G.; Pathak, H. Yield and phosphorus transformations in a rice-wheat system with crop residue and phosphorus management. Soil Sci. Soc. Am. J. 2007, 71, 1500-1507. [CrossRef]

24. Li, X.; Lu, J.; Wu, L.; Chen, F. The difference of potassium dynamics between yellowish red soil and yellow cinnamon soil under rapeseed (Brassica napus L.), rice (Oryza sativa L.) rotation. Plant Soil 2009, 320, 141-151. [CrossRef] 
25. Moldenhauer, K.; Slaton, N. Rice Growth and Development. In Rice Production Handbook; University of Arkansas Division of Agriculture Cooperative Extension Service: Little Rock, AR, USA, 2006; pp. 1-14.

26. Yoshida, S.; Matsuda, T.; Tajima, S.; Nitta, Y. Effect of high temperature at ripening stage on the reserve accumulation in seed in some rice cultivars. Plant Prod. Sci. 1981, 5, 160-168.

27. Ghoneim, A.; Ueno, H.; Ebid, A. Nutrients dynamics in komatsuna (Brassica campestris L.) growing soil fertilized with biogas slurry and chemical fertilizer using ${ }^{15} \mathrm{~N}$ Isotope dilution method. Pak. J. Biol. Sci 2006, 9, 2426-2431. [CrossRef]

28. Ebid, A.; Ueno, H.; Ghoneim, A.; Asagi, N. Uptake of carbon and nitrogen through rice root from ${ }^{13} \mathrm{C}$ and ${ }^{15} \mathrm{~N}$ dual-labeled maize residues compost. Int. J. Biol. Chem. 2007, 1, 75-83. [CrossRef]

29. Singh, B.K.; Modgal, S.C. Dry-matter production, phosphorus and potassium uptake as influenced by levels and methods of nitrogen application in rainfed upland rice. Plant Soil 1978, 50, 691-701. [CrossRef]

30. Huanga, D.; Denga, R.; Wana, J.; Zenga, G.; Xuea, W.; Xiaofeng, W.X.; Zhoua, C.; Liang Hua, L.; Liua, X.; Xua, P.; et al. Remediation of lead-contaminated sediment by biochar-supported nanochlorapatite: Accompanied with the change of available phosphorus and organic matters. J. Hazard. Mat. 2018, 348, 109-116. [CrossRef]

31. Van Zwieten, L.; Kimber, S.; Morris, S.; Chan, K.Y.; Downie, A.; Rust, J.; Joseph, S.; Cowie, A. Effects of biochar from slow pyrolysis of paper mill waste on agronomic performance and soil fertility. Plant Soil 2010, 327, 235-246. [CrossRef]

32. Chan, K.Y.; Van Zwieten, L.; Meszaros, I.; Downie, A.; Joseph, S. Agronomic values of greenwaste biochar as a soil amendment. Aust. J. Soil Res. 2007, 45, 629-634. [CrossRef]

33. Pierzynski, G.M. The chemistry and mineralogy of phosphorus in excessively fertilized soils. Crit. Rev. Environ. Sci. Technol. 1991, 21, 265-295. [CrossRef]

34. Rengel, Z.; Marschner, P. Nutrient availability and management in the rhizosphere: Exploiting genotypic differences. New Phytol. 2005, 168, 305-312. [CrossRef]

35. Zhou, K.; Binkley, D.; Doxtader, K.G. A new method for estimating gross phosphorus mineralization and immobilization rates in soils. Plant Soil 1992, 147, 243-250. [CrossRef]

36. Guo, J.H.; Liu, X.J.; Zhang, Y.; Shen, J.L.; Han, W.X.; Zhang, W.F.; Christie, P.; Goulding, K.W.T.; Vitousek, P.M.; Zhang, F.S. Significant acidification in major Chinese croplands. Science 2010, 327, 1008-1010. [CrossRef]

37. Qiao, J.F.; Liu, Z.H.; Deng, S.Y.; Ning, H.F.; Yang, X.Y.; Lin, Z.M.; Li, G.H.; Wang, Q.S.; Wang, S.H.; Ding, Y.F. Occurrence of perfect and imperfect grains of japonica rice as affected by nitrogen fertilizer. Plant Soil 2011, 349, 191-202. [CrossRef]

38. Bi, J.; Liu, Z.; Lin, Z.; Alim, M.A.; Rehmani, M.I.; Li, G.; Wang, Q.; Wang, S.; Ding, Y. Phosphorus accumulation in grains of japonica rice as affected by nitrogen fertilizer. Plant Soil 2012, 369. [CrossRef]

39. Carter, S.; Shackley, S.; Sohi, S.; Suy, T.B.; Haefele, S. The Impact of Biochar Application on Soil Properties and Plant Growth of Pot Grown Lettuce (Lactuca sativa) and Cabbage (Brassica chinensis). Agronomy 2013, 3, 404-418. [CrossRef]

40. Sommer, S.G.; Hutchings, N.J. Ammonia emission from field applied manure and its reduction. Eur. J. Agron. 2001, 15, 1-15. [CrossRef]

41. Agusalim, M.; Utomo, W.H.; Syechfani, M.S. Rice Husk Biochar for Rice Based Cropping System in Acid Soil 1. The Characteristics of Rice Husk Biochar and Its Influence on the Properties of Acid Sulfate Soils and Rice Growth in West Kalimantan, Indonesia. J. Agric. Sci. 2010, 2, 39-47.

42. Glaser, B.; Lehmann, J.; Zech, W. Ameliorating physical and chemical properties of highly weathered soils in the tropics with charcoal a review. Biol. Fert. Soil 2002, 35, 219-230. [CrossRef]

43. Rondon, M.A.; Lehmann, J.; Ramirez, J.; Hurtado, M. Biological nitrogen fixation by common beans (Phaseolus vulgaris L.) increases with bio-char additions. Biol. Fert. Soil 2007, 43, 699-708. [CrossRef]

44. Wu, D.; Quan, X.; Zhang, Y.; Zhao, Y. Long-term operation of a compost-based biofilter for biological removal of $n$-butyl acetate, p-xylene and ammonia gas from an air stream. Biochem. Eng. J. 2006, 32, 84-92. [CrossRef]

45. Kissel, D.E. Management of Urea Fertilizers; Northwest Research-Extension Center, Kansas State University: Manhattan, KS, USA, 1988; p. 8.

46. Choudhury, A.T.M.A.; Khanif, Y.M. Evaluation of effects of nitrogen and magnesium fertilization on rice yield and fertilizer nitrogen efficiency using $15 \mathrm{~N}$ tracer technique. J. Plant Nutr. 2001, 24, 855-871. [CrossRef]

47. Vitosh, M.L. Nitrogen Fertilizers, N-P-K Fertilizers, Extension Bulletin E-896; Michigan State University: East Lansing, MI, USA, 1990.

48. Oberson, A.; Joner, E.J. Microbial Turnover of Phosphorus in Soil. In Organic Phosphorus in the Environment; Turner, B.L., Frossard, E., Baldwin, D.S., Eds.; CABI: Wallingford, UK, 2005; pp. 133-164.

49. Mahdi, S.S.; Hassan, G.I.; Hussain, A.; Rasool, F. Phosphorus availability issue-Its fixation and role of Phosphate solubilizing Bacteria in Phosphate solubilization. Res. J. Agric. Sci. 2011, 2, 174-179.

50. Sharma, S.B.; Sayyed, R.Z.; Trivedi, M.H.; Gobi, T.A. Phosphate solubilizing microbes: Sustainable approach for managing phosphorus deficiency in Agricultural soils. Springer Plus 2013, 2, 587. [CrossRef]

51. Ohtake, H.; Wu, H.; Imazu, K.; Ambe, Y.; Kato, J.; Kuroda, A. Bacterial phosphonate degradation, phosphite oxidation and polyphosphate accumulation. Resour. Conserv. Recycl. 1996, 18, 125-134. [CrossRef]

52. Silveira, M. Soil acidity and its relationship with nutrient use efficiency. Fla. Cattlem. Livest. J. 2013, 1-4.

53. Gamage, D.A.S. Development of Nutrient Management Technologies for Sustainable Rice Farming for Mitigating Water and Atmospheric Pollution. Ph.D. Thesis, Postgraduate Institute of Agriculture, University of Peradeniya, Peradeniya, Sri Lanka, 2015 
54. Dharmakeerthi, R.S.; Indraratne, S.P.; Kumaragamage, D. Manual of Soil Sampling and Analysis, Special Publication No 10; Soil science society of Sri Lanka: Colombo, Sri Lanka, 2007.

55. Gamage, D.A.S.; Sarachchandra, G.W.N.L.; Basnayake, B.F.A.; Costa, W.A.J.M. Lysimeter Simulation of Paddy Straw Landfill Bioreactor for Optimum Gas Production. Trop. Agric. Res. 2010, 21, 177-188. [CrossRef]

56. Gamage, D.A.S.; Wijesekara, S.S.R.M.D.H.R.; Sarathchandra, G.W.N.L.; Basnayake, B.F.A.; Costa, W.A.J.M. Estimation of Nitrate and Phosphate Leaching from Lysimeter Simulation of Rice Straw Landfill Bioreactor and Evaluation of Fertilizer Quality of Resulting Compost. Trop. Agric. Res. 2011, 22, 220-228. [CrossRef] 